\title{
シリーズ教育講座「原著から今日まで 一代表的疾患の変遷一」
}

\section{5.メニエール病：原著から今日まで}

\section{武田＼cjkstart憲昭}

\section{History of Meniere's disease based on Meniere's original publications}

\author{
Noriaki Takeda \\ Department of Otolaryngology, University of Tokushima School of Medicine
}

In 1861, Prosper Meniere reported pathological findings consisting of bloody exudate in the semicircular canals of a girl who had died after suffering from vertigo, tinnitus and deafness, suggesting that an inner ear lesion, in addition to cerebral accidents, could cause vertigo. In 1867, Politzer described a similar patient as having “Meniere’s disease.” In 1938, Yamakawa and Hallpike independently discovered the important pathological findings of endolymphatic hydrops in patients with Meniere's disease. In 2007, Naganawa visualized endolymphatic hydrops in living patients with Meniere's disease using Gd-enhanced MRI. The further development of MRI technology is expected to yield deeper insights into the pathophysiology of Meniere's disease.

Key words: Meniere's disease, endolymphatic hydrops, endolymphatic sac surgery, MRI visualization of endolymphatic hydrops

\section{Meniere の原著論文}

メニエール病にその名前が冠されている Prosper Meniereは, 1799年 6 月18日生まれのフラン ス人医師である。1861年の 1 月， 2 月， 4 月， 6 月， 9 月に Gaz. Med. de Parisに 5 編の論文を発 表し, めまいが内耳病変から発症することを報告 した。この 5 編の論文の英訳がActa OtoLaryngologica Supplement 162: Meniere's original papers に掲載されている ${ }^{1)}$ 。また，この論文の日 本語の抄録が「メニエール病」の $4 \sim 7$ ページに 掲載されている2)。有名な少女例を含む 5 番目の 論文（9月）が，その年の 1 月に Meniereによ りフランス医学アカデミーで発表されており, 1 番目の論文（1月）はその際の討論の内容である

徳島大学耳鼻咽喉科
ことから 1 連の論文と見なして，メニエールの 4 編の論文と記載されている場合もある。

Meniere が報告した有名な少女例は，ある冬の 夜, 棍馬車で旅行中に突然のめまい, 難聴, 嘔吐 を発症し，病院に入院するも5 日目に死亡した。 剖検で中枢神経には異常がなく，三半規管に血性 渗出物が充満していた。白血病による内耳出血説 と, 内耳炎からの髄膜炎説がある。 Meniere はめ まいの原因として当時, 考えられていた脳のうっ 血ではなく, Flourensの沜の内耳破壊実験など から内耳病変からもめまいが発症すると考えるべ きであると述べている。

しかし，この Meniereの画期的な論文は，当 時のフランス医学アカデミーでは評価されなかっ た。Meniereは, 論文発表の翌年の1862年 2 月 7 日に62歳で亡くなった。Meniereの論文の価値を 


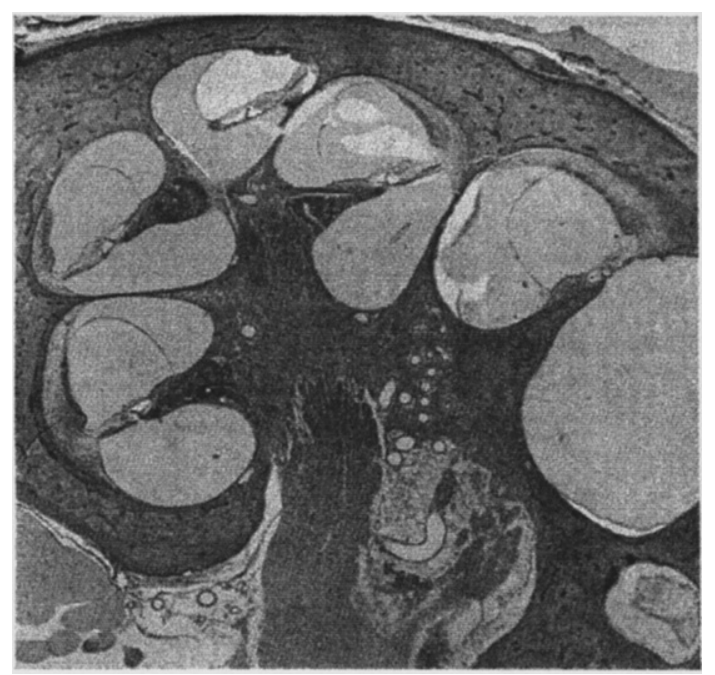

図 1 山川が1929年に発表したモルモットの内耳炎 に伴う内リンパ水腫。文献 4 より Springer の許可を得て転載。

まず評価したのは, ウイーン大学の Politzerであ った。Politzer は1867年に内耳出血によるめまい 症例を発表し, 内耳性めまいをメニエール病 (Meniereschen Krankheitsform) と呼ぶことを提 唱した3)。その結果, メニエール病という病名が 広く世界に普及した。その後, 内耳性めまいを総 称するメニエール症候群から, 難聴と耳鳴を伴う 回転性めまいを繰り返すメニエール病が区別され るようになり, 1938年の山川, Hallpikeによるメ ニエール病患者における内リンパ水腫の発見に繋 がっていった。

Wittmaack による内リンパ水腫の発見の原著 論文

内リンパ水腫を初めて報告したのは, ハンブル グ大学の Wittmaack である。Wittmaack は1924年 に細菌性内耳炎症例の側頭骨病理組織においてラ イスネル膜の膨隆を認め,この所見を「hydropische Degeneration」や「hydrops labyrinthi」と 表記して報告した4)。これが内リンパ水腫の最初 の報告と思われる。しかし，この論文には側頭骨 病理組織写真が揭載されていない。

最初の内リンパ水腫の側頭骨病理組織写真は, Wittmaackのもとに留学していた山川（強四郎, 後の阪大教授, メニエール病の内リンパ水腫を発 見）が1929年に報告した。Yamakawaはヒ素によ

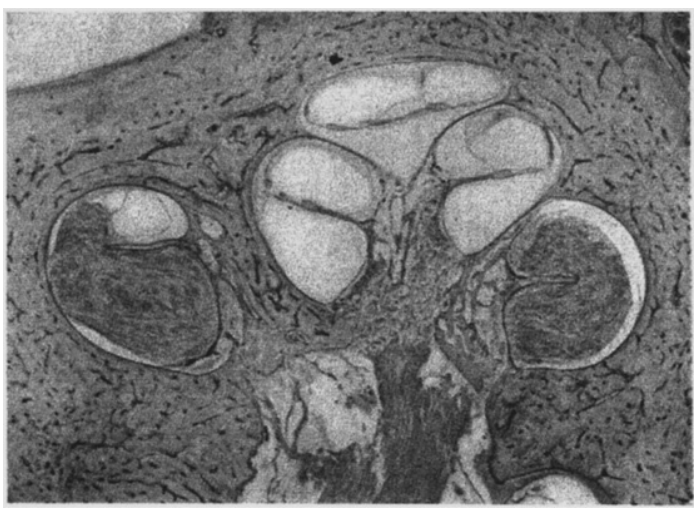

図2 Wittmaackが1930年に発表したヒトの内リン パ水腫。文献 5 より Springerの許可を得て 転載。

る内耳炎により障害されたモルモットの内耳に内 リンパ水腫を認め, hydropische Degeneration と 記載し, その側頭骨病理組織写真を掲載した5)。 ライスネル膜の膨隆に加え, 内外リンパに炎症細 胞や precipitate が認められている（図1)。最初 のヒトの内リンパ水腫の側頭骨病理組織写真は,

Wittmaack が1930年に報告しだ)。この症例は, ハンブルグ大学のエッペンドルフ病院の細菌学教 授であったPlautであり, 螖牛の基底回転は neurofibroma で充満し, 第 2 回転と頂回転に hydropische Degenerationを認めた（図 2 )。hydropische Degenerationは変性性内リンパ水腫 (degenerative hydrops) であり, 内耳炎や神経線維 腫により内耳が障害された場合に認められる内リ ンパ水腫の名称と思われる。なお, Plautの名前 は, Plaut-Vincent angina の病名に残っている。

山川, Hallpikeによるメニエール病患者にお ける内リンパ水腫の発見の原著論文

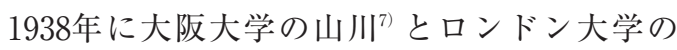
Hallpike $e^{8)}$ が, 独立してメニエール病患者の側頭 骨病理組織に内リンパ水腫を発見した。Hallpike は, 脳外科医の Cairns が Dandy 手術（第 8 脳神 経切断術）を行った後に死亡したメニエール病患 者 2 例の側頭骨病理組織において, 患側耳に内リ ンパ水腫を認めた。この頃には, Wittmaackが発 見した内リンパ水腫が欧米では広く認められてい たようで,この論文には endolymphatic hydrops と記載されている。 Hallpike は内リンパ圧の上昇 


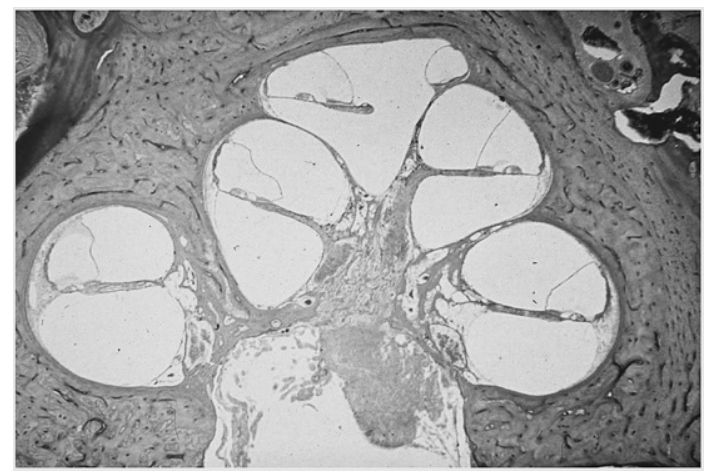

図3山川が1938年に発見したメニエール病患者の 内リンパ水腫（大阪大学医学部耳鼻咽喉科学 教室所蔵)

が内耳の虚血を引き起こし, 内耳機能が低下する ことによりメニエール病のめまい発作が引き起こ されると考察した。この仮説は, 発作時に健側耳 向きの麻痺性眼振を認めた 1 例の病態を説明でき るが, 発作時に患側耳向きの刺激性眼振を認めた もう 1 例の病態を説明できない。

山川は，58歳でメニエール病を発症して60歳で 肺炎により死亡した大阪大学産婦人科教授の緒方 の遺言により側頭骨病理組織検査を行い, 患側耳 に内リンパ水腫を認めた（図 3 )。山川は1929年 にモルモットの内リンパ水腫を報告していたた め, 緒方の側頭骨病理組織の異常が内リンパ水腫 であることを直ちに理解した。しかし，緒方の内 リンパ水腫は変性性内リンパ水腫と大きく異な り, 内外リンパに炎症細胞や precipitateを全く 認めない非炎症性の内リンパ水腫であった。さら に山川は緒方の主治医として, 患側耳の低音域の 難聴に加えて発作時の患側向きの眼振を認めてい たことから, 発作時に患側耳が興奮していること を理解していた。そこで山川は, 内リンパ水腫に よる内リンパ圧の立進が内耳を興奮させ, メニエ ール病の発作を引き起こしていると考察した。そ の後, Wittmaack と山川は, この内リンパ水腫を Reizhydrops（興奮性内リンパ水腫, irritative hydrops）と呼んだ。

メニエール病の発作は, 1960年代にハーバード 大学耳鼻咽喉科教授の Schuknechtにより提唱さ れた membrane rupture theory が広く認められて いる ${ }^{9)}$ 。なわち, 内リンパ水腫による内リンパ
圧の上昇がライスネル膜の破綻を引き起こし，高 $\mathrm{K}^{+}$の内リンパが前庭階の外リンパに流入する。 その結果, 前庭神経の脱分極が生じて刺激性眼振 が解発され，それに引き続く前庭神経の過分極に より麻痺性眼振が解発される。一方1920年代に Wittmaack は, 内耳前庭の感覚上皮が内リンパ圧 に反応するというトーヌス説（tonus theory）を 提唱した ${ }^{10)}$ 。Wittmaack と山川はトーヌス説に基 づき, メニエール病の発作期の刺激性眼振を内リ ンパ水腫による内リンパ圧の上昇が前庭感覚上皮 を興奮させたためと考えた。その後トーヌス説は 長く忘れ去られていたが, 1983年にベルリン大学 の Scherer による微小重力下での温度眼振の解発 の発見により，再評価が行われるようになっ た ${ }^{11)}$ 。

\section{内リンパ囊開放術の原著論文}

メニエール病患者の内耳に内リンパ水腫が発見 される以前に, 内リンパ圧の立進が内耳を興奮さ せてメニエール病の発作を引き起こしていると考 えたのはボルドー大学の Portmannである ${ }^{12)} 。$ 1920年代前半に行われた彼の画期的な動物実験に 基づいて1926年に内リンパ囊開放術を行い, 1927 年に論文で発表した ${ }^{13)}$ 。この手術は, 内耳機能を 保存し改善することもできた世界で最初の内耳手 術である。しかし, 同年の American Otological Societyにおいて Portmannの内リンパ嚢開放術 はShambaugh Sr.に厳しく批判され, 長く忘れ 去られた術式となっていた ${ }^{14)}$ 。Portmannによる と，世界で 2 番目に内リンパ囊開放術を行ったの は大阪大学の内藤である。Naito はさまざまな種 類の実験的内リンパ水腫を作成したが, 特にモル モットの内リンパ囊を閉塞すると内リンパ水腫が 形成されることを発見し, 内リンパ囊に内リンパ

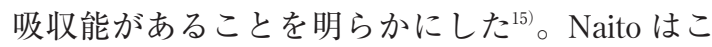
の動物実験に基づき, Portmannの mastoid shunt ではなく subarachnoid shuntの内リンパ嚢開放 術を行った ${ }^{15)}$ 。内藤が内リンパ囊閉塞により作成 した内リンパ水腫は, Retentionshydrops（貯留 性内リンパ水腫, retention hydrops）と考えられ る。なお, 内藤の内リンパ嚢閉塞による内リンパ 水腫は1954年に英文論文で発表されており，よく 引用される Kimura の1967年の報告 ${ }^{16)} よ り 10$ 年以 上も早い。 


\section{3 種類の内リンパ水腫}

以上の歴史的経過から, 内リンパ水腫としての 形態は同じでも, その機能により 3 種類の内リン パ水腫が存在している可能性がある ${ }^{17)}$ 。すなわ ち, 障害された内耳に認められて麻痺性眼振を伴 う変性性内リンパ水腫, 内リンパ圧の上昇により メニエール病の臨床症状を引き起こして発作の初 期には刺激性眼振を伴う刺激性内リンパ水腫, 内 リンパ圧の上昇がなく眼振を伴わない貯留性内リ ンパ水腫の 3 種類である。

\section{今日までの変遷}

Politzer が末梢性めまいをメニエール病と名付 けたが, その後, Politzer がメニエール症候群の 用語も使ったため, 混乱が長く続いた。1952年に Dix と Hallpike が，メニエール病と区別するべき 末梢性めまいとして良性発作性頭位めまい症や前 庭神経炎の概念を明らかにした ${ }^{18)}$ 。これに対し て, メニエール病は内リンパ水腫を病態とし, め まい, 難聴, 耳鳴を主徵とする疾患概念が確立さ れ, メニエール症候群の用語は用いられなくなっ た。

その後, このメニエール病の疾患概念に基づ き,メニエール病の診断基準が提案され, 改訂さ れてきた。まず1972年に, AAOO がメニエール 病の診断基準を発表した。その後, AAO-HNS に よる1985年の改訂を経て，1995年に改訂された AAO-HNS のメニエール病の診断基準が, 長く世

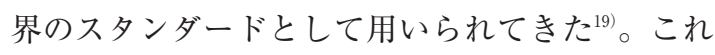
までの側頭骨病理組織学的研究により, AAOHNS の診断基準によりメニエール病と診断され た患者のほとんどの側頭骨に内リンパ水腫が認め られたと報告されている。 腫がメニエール病の全ての臨床症状を引き起こす かについては異論もある。

最近, Naganawaらにより造影 MRIによる内 リンパ水腫の画像診断が開発され, メニエール病 患者の内耳に高頻度で内リンパ水腫が認められる ことが明らかになった ${ }^{21)}$ 。メニール病の病態で ある内リンパ水腫が生きた患者で確認できるよう になった意義は大きい。一方で, メニエール病患 者の健側耳やメニエール病以外の耳疾患の患者の 内耳にも内リンパ水腫が認められることも明らか になった ${ }^{22)}$ 。メニエール病を発症させることがで きるのは刺激性内リンパ水腫であるが, 造影
MRI では変性性内リンパ水腫や貯留性内リンパ 水腫と区別できないからかも知れない。

一方, メニエール病が家族性に発症することな どから,メニエール病が遺伝子異常により発症す ると考える研究者もいる。事実, 原因遺伝子の探 索により,メニエール病の原因となる候補遺伝子 が報告されている ${ }^{23)}$ 。最近, Barany Societyから メニエール病の診断基準が提案された。この診断 基準の背景には, メニエール病遺伝子異常説があ ると推定される。内リンパ水腫は遺伝子異常の 1 つの表現型でメニエール病の病態ではないとの考 え方もあるが, 遺伝子異常の結果生じた内リンパ 水腫がメニエール病の症状を引き起している可能 性もある。

おわりに

メニエールが内耳性めまいに関する原著論文を 発表してから150年以上が過ぎた。Wittmaackが あらかじめ変性性内リンパ水腫を報告していたか らこそ, 山川はメニエール病患者の側頭骨病理組 織に刺激性内リンパ水腫を発見することができ た。内藤の貯留性内リンパ水腫の作成は, 内リン パ裹開放術に理論的根拠を与えた。最近の造影 MRIによる内リンパ水腫画像検査により, 生き た患者の内耳の内リンパ水腫を可視化できるよう になったが, 新たな疑問も生まれた。遺伝子を含 む今後のメニエール病研究の発展が期待される。

\section{文献}

1) Atkinson M: Meniere's original papers: reprinted with an English translation together with commentaries and biographical sketch. Acta Otolaryngol Suppl: 162, 1961

2 ) 檜 学, 内藤 儶, 大和田健次郎, 他 : 又 ニエール病. 医学書院, 東京, 1964

3 ) Politzer A: Uber Lasion des Labyrinthes. Archiv f Ohrenheilkunde 2: 88-99, 1867

4 ) Wittmaack K: Uber die intravitale Entstehung yon Kollups- und Degenerationsvorgiingen an den Sinnesendstellen des inneren Ohres. Arch Ohr Nas u Kehlk Heilk 112: 43-52, 1924

5 ) Yamakawa K: Die Wirkung der Arsenigen Saure auf das Ohr. Arch Ohr Nas u Kehlk Heilk 123: 238-296, 1929

6 ) Wittmaack K: Uber den Tonus der Sinne- 
sendstellen des Innenohres. 5. Mitteilung: Die Menieresche Krankheit im Lichte der Tonuslehre. Arch Ohr Nas u Kehlk Heilk 124: 177-198, 1930

7 ）山川強四郎：メニエール氏症候ヲ呈セシ患者 八聴器. 日耳鼻 $44: 2310-2312,1938$

8 ) Hallpike CS, Cairns H: Observations on the pathology of Meniere's syndrome. J Laryngol Otol 53: 625-655, 1938

9 ) Schuknecht HF: Meniere's disease: A correlation of symptomatology and pathology. Laryngoscope 73: 651-665, 1963

10) Wittmaack K: Uber den Tonus der Sinnesendstellen des Innenohres. 1. Mitteilung: Tonuszeichen im morphologischen Bilde. Arch Ohr Nas u Kehlk Heilk 114: 278-308, 1926

11) Scherer H, Brandt U, Clarke AH, et al.: European vestibular experiments on the Spacelab-1 mission: 3. Caloric nystagmus in microgravity. Exp Brain Res 64: 255-263, 1986

12) Portmann G, Shambaugh GE, Arenberg IK, et al.: The first inner ear surgery to conserve or improve a sensory hearing loss: a candid discussion of the first 50 years of endolimphatic sac surgery for hydrops with innovator. Rev Laryngol 99: 277-298, 1978

13) Portmann G: Surgical Treatment by opening the saccus endolymphaticus. Arch Otolaryngol 6: 309-319, 1927

14）文献12の316-319の Discussionに, American Otological SocietyにおけるPortmanの内リ ンパ襄解放術の発表に対する質疑応答が記載 されている。

15) Yamakawa K, Naito $T$ : The modification of Portmann's operation for Meniere's disease: Yamakawa-Naito operation. Med J Osaka Univ 5: 167-175, 1954

16) Kimura RS: Experimental blockage of the endolymphatic duct and sac and its effect on the inner ear of the guinea pig: a study on endolymphatic hydrops. Ann Otol Rhinol Laryngol 76: 664-687, 1967
17) Wittmaack K: Die Oroth- und Pathobiologie des Labyrinthes. Georg Thieme Verlag, Stuttgart, 1956

18) Dix MR, Hallpike CS: The pathology, symptomatology and diagnosis of certain common disorders of the vestibular system. Ann Otol Rhinol Laryngol 61: 987-1016, 1952

19) Committee on Hearing and Equilibrium: Guidelines for the diagnosis and evaluation of therapy in Meniere's disease. Otolaryngol Head Neck Surg 113: 181-185, 1995

20) Foster CA, Breeze RE: Endolymphatic hydrops in Meniere's disease: cause, consequence, or epiphenomenon? Otol Neurotol 34: 1210-1214, 2013

21) Nakashima T, Naganawa S, Sugiura M, et al.: Visualization of endolymphatic hydrops in patients with Meniere's disease. Laryngoscope 117: 415-420, 2007

22) Pyykkö I, Nakashima T, Yoshida T, et al.: Meniere's disease: a reappraisal supported by a variable latency of symptoms and the MRI visualization of endolymphatic hydrops. BMJ Open 3: e 001555, 2013

23) Requena $T$, Cabrera S, Martín-Sierra C, et al.: Identification of two novel mutations in FAM $136 \mathrm{~A}$ and DTNA genes in autosomaldominant familial Meniere's disease. Hum Mol Genet 24: 1119-1126, 2015

注：文献 3，4，5，6，10が掲載されている $\mathrm{Ar}$ chiv f Ohrenheilkunde と Arch Ohr Nas u Kehlk Heilk はそれぞれ Archiv für Ohrenheilkunde と Archiv für Ohren-, Nasen- und Kehlkopfheilkunde の略であり, 現在の European Archives of Oto-Rhino-Laryngology and Head \& Neckの前身である。これらのドイ ツ語の論文は, Springerのホームページから 検索して PDF ファイルをダウンロードする ことができる。

利益相反に該当する事項はない。 